\title{
An efficient method for high-fidelity messenger RNA amplification from a small amount of total RNA
}

\author{
MITSURU CHIBA $^{1,2}$, SAYA ASARI $^{3}$, MISAKO KIMURA $^{3}$ and TOSHIYA NAKAMURA ${ }^{1,2}$ \\ ${ }^{1}$ Department of Biomedical Sciences, Division of Medical Life Sciences; \\ ${ }^{2}$ Research Center for Biomedical Sciences; ${ }^{3}$ Department of Medical Technology, Hirosaki \\ University Graduate School of Health Sciences, Hirosaki, Aomori 036-8564, Japan
}

Received September 11, 2012; Accepted October 1, 2012

DOI: $10.3892 /$ br.2012.15

\begin{abstract}
Comprehensive analyses of gene expression have been carried out by the development of microarrays and deep sequencers. However, it is difficult to obtain comprehensive information on gene expression from a small amount of ribonucleic acid (RNA). Therefore, we investigated the reproducibility and application of T7 RNA polymerase-mediated transcription, adaptor ligation and polymerase chain reaction (PCR) amplification, followed by $\mathrm{T} 7$ transcription (TALPAT), an efficient method for amplifying poly (A)-positive RNA, such as messenger RNA (mRNA). When amplified complementary RNA (cRNA) was electrophoresed, a large number of amplified cRNA was detected in the size of $0.2-0.5 \mathrm{~kb}$. This indicates that the region up to $0.2-0.5 \mathrm{~kb}$ from the $3^{\prime}$ end of the original mRNA was amplified by the TALPAT method. Seven housekeeping genes, glyceraldehyde-3-phosphate dehydrogenase $(G A P D H)$, hydroxymethylbilane synthase $(H M B S)$, hypoxanthine phosphoribosyltransferase (HPRT1), ribosomal protein L13a (RPL13A), succinate dehydrogenase complex $(S D H A)$, TATA box-binding protein $(T B P)$ and ubiquitin $\mathrm{C}$ $(U B C)$, showed high reproducibility (square of the correlation coefficient, $\mathrm{R}^{2}=0.9954$ ), according to scatter plots of $\mathrm{Ct}$ values obtained in the real-time PCR analysis of amplified cRNA. In addition, relative expression ratios of amplified cRNA of the seven housekeeping genes were approximately equal to the ratio of the original RNA solution. Furthermore, cRNA was amplified from $20 \mathrm{pg}$ total RNA. In the present study, we confirmed the characteristics of mRNA amplification using the TALPAT method. This method may be applicable to mRNA and poly (A)-positive non-coding RNA amplification, using a
\end{abstract}

Correspondence to: Dr Mitsuru Chiba, Department of Biomedical Sciences, Division of Medical Life Sciences, Hirosaki University Graduate School of Health Sciences, 66-1 Hon-cho, Hirosaki, Aomori 036-8564, Japan

E-mail: mchiba32@cc.hirosaki-u.ac.jp

Key words: $\mathrm{T} 7$ in vitro transcription, complementary ribonucleic acid synthesis, mRNA amplification, adaptor ligation, real-time polymerase chain reaction small amount of RNA from single, laser-captured and sorted cells, as well as exosomes from serum, urine and body fluids.

\section{Introduction}

Gene expression is a multistep process involving the transcription, translation and turnover of messenger RNA (mRNA) and proteins. Recently, analyses of gene expression have been used to understand various biological phenomena. Reverse-transcription polymerase chain reaction (RT-PCR) is a method used for analyzing the mRNA expression of a single gene. During the 1990s, a microarray method, with the potential to analyze the expression of a large number of genes, was developed (1). In the 2000s, the word 'transcriptome' was coined, following the development of the microarray method and sequencing of the entire human genome (2-4) as well as the full-length cDNA $(5,6)$. More recently, transcriptome analyses have been accelerated by the development of deep sequencers.

Microarray analysis is a method that employs Cyanine 3 (Cy3)- and/or Cyanine 5 (Cy5)-labeled complementary RNA (cRNA) or cDNA, and requires a large amount of total RNA. Therefore, it is difficult to obtain comprehensive information of gene expression from a small amount of samples, such as clinical samples, tissue sections and cells sorted by flow cytometry. Aoyagi et al developed the T7 RNA polymerase-mediated transcription, adaptor ligation and PCR amplification followed by the T7-transcription (TALPAT) method, which markedly improved amplification efficiency, to resolve this issue $(7,8)$. The TALPAT method combines the T7 in vitro transcription (9) with the adaptor ligation PCR method $(10,11)$ and is able to amplify a small amount of mRNA to 5-10 mg cRNA $(7,8)$. Comprehensive analyses of gene expression from a small amount of total RNA were enabled by the development of the TALPAT method. However, this method is not commonly known as the amplification method for a small amount of total RNA.

In the present study, we investigated the reproducibility and application of the TALPAT method using a small amount of diluted total RNA.

\section{Materials and methods}

Cell line and cell culture. The human A549 lung cancer cell line (JCRB0076) was purchased from the Human Science 
Research Resources Bank (Osaka, Japan). The cells were cultured in Dulbecco's minimum essential medium (DMEM) supplemented with $10 \%$ fetal bovine serum (FBS), $100 \mathrm{U} / \mathrm{ml}$ penicillin and $100 \mu \mathrm{g} / \mathrm{ml}$ streptomycin. The cells were cultured at $37^{\circ} \mathrm{C}$ in an atmosphere of $5 \% \mathrm{CO}_{2}$. Cell counts were performed by trypan blue staining.

Total RNA extraction. Total RNA from the A549 cells was extracted using ISOGEN (Nippon Gene, Tokyo, Japan), according to the manufacturer's instructions. The concentration of total RNA extracted was examined using the NanoDrop Spectrophotometer (ThermoFisher Scientific, Wilmington, DE, USA), according to the manufacturer's instructions.

TALPAT-step 1. To synthesize first-strand cDNA, $1 \mu \mathrm{l}$ of $100 \mu \mathrm{M}$ T7-oligo $\mathrm{dT}_{24}$ primer (5'-pGGCCAGTGAATTGTA ATACGACTCACTATAGGGAGGCGGTTTTTTTTTTTTT TTTTTTTTTTT-3') was added to $10 \mu 1$ of a solution containing total RNA. The solution was incubated at $65^{\circ} \mathrm{C}$ for $10 \mathrm{~min}$ and then chilled on ice. Four microliters of $5 \mathrm{X}$ first-strand buffer (Life Technologies, Carlsbad, CA, USA), $2 \mu \mathrm{l}$ of $0.1 \mathrm{M}$ dithiothreitol (DTT), $1 \mu \mathrm{l}$ of $10 \mathrm{mM}$ dNTP and $1 \mu \mathrm{l}$ of $40 \mathrm{U} / \mu 1$ RNasin Plus RNase inhibitor (Promega, Madison, WI, USA) were added to the RNA solution. The solution was incubated at $37^{\circ} \mathrm{C}$ for $2 \mathrm{~min}$, and $1 \mu \mathrm{l}$ of $200 \mathrm{U} / \mu \mathrm{l}$ SuperScript II RT (Life Technologies) was then added to it. The solution was incubated at $37^{\circ} \mathrm{C}$ for $60 \mathrm{~min}$. For the synthesis of second-strand cDNA, $91 \mu \mathrm{l}$ of RNase-free water, $30 \mu 1$ of $5 \mathrm{X}$ second-strand buffer (Life Technologies), $3 \mu \mathrm{l}$ of $10 \mathrm{mM}$ dNTPs, $4 \mu \mathrm{l}$ of $10 \mathrm{U} / \mu \mathrm{l}$ E. coli DNA polymerase I (Life Technologies), $1 \mu \mathrm{l}$ of $10 \mathrm{U} / \mu 1$ $E$. coli DNA ligase (Life Technologies) and $1 \mu \mathrm{l}$ of $2 \mathrm{U} / \mu \mathrm{l}$ E. coli RNase H (Life Technologies) were added to the first-strand cDNA solution. The solution was incubated at $16^{\circ} \mathrm{C}$ for $2 \mathrm{~h}$. For the end smoothing of double-stranded cDNA, $2 \mu \mathrm{l}$ of $5 \mathrm{U} / \mu 1 \mathrm{~T} 4$ DNA polymerase (Life Technologies) was added. The solution was incubated at $16^{\circ} \mathrm{C}$ for $5 \mathrm{~min}$. The synthesized double-strand cDNA was purified using phenol/chloroform, isopropanol and ethachinmate (Nippon Gene). The obtained pellets were washed twice with $70 \%$ ethanol and resolved in $6.3 \mu 1$ RNase-free water.

TALPAT-step 2. To synthesize cRNA by T7 in vitro transcription, the AmpliScribe T7-Flash Transcription kit (Epicentre Biotechnologies, Madison, WI, USA) was used. Two microliters of 10X reaction buffer; $2.0 \mu 1$ of $100 \mathrm{mM}$ DTT as well as $1.8 \mu \mathrm{l}$ of each of $100 \mathrm{mM}$ dATP, dCTP, dGTP and dUTP; $0.5 \mu \mathrm{l}$ of RiboGuard RNase Inhibitor and $2 \mu \mathrm{l}$ of AmpliScribe T7-Flash Enzyme Solution were added to $6.3 \mu 1$ of the double-strand cDNA solution described above. The solution was then incubated at $37^{\circ} \mathrm{C}$ for $16 \mathrm{~h}$. To degrade double-strand cDNA, $1 \mu \mathrm{l}$ of RNase-free DNase I solution was added to the solution. The solution was incubated at $37^{\circ} \mathrm{C}$ for $15 \mathrm{~min}$, and $400 \mu \mathrm{l}$ of ISOGEN reagent was then added to it. The synthesized cRNA was extracted using ISOGEN reagent, according to the manufacturer's instructions. The cRNA pellets were resuspended in $10 \mu \mathrm{l}$ of RNase-free water.

TALPAT-step 3. Random hexamer primer (1 $\mu \mathrm{l})$ was added to the cRNA solution obtained from step 2. Each solution was incubated at $68^{\circ} \mathrm{C}$ for $10 \mathrm{~min}$ and then chilled on ice.
To synthesize first-strand cDNA from cRNA, $4 \mu \mathrm{l}$ of $5 \mathrm{X}$ first-strand buffer (Life Technologies), $2 \mu \mathrm{l}$ of $0.1 \mathrm{M}$ DTT, $1 \mu \mathrm{l}$ of $10 \mathrm{mM} \mathrm{dNTP}$ and $1 \mu \mathrm{l}$ of $40 \mathrm{U} / \mu \mathrm{l}$ RNasin Plus RNase inhibitor (Promega) were added. The solution was incubated at $37^{\circ} \mathrm{C}$ for $2 \mathrm{~min}$. Then, $1 \mu \mathrm{l}$ of $200 \mathrm{U} / \mu \mathrm{l}$ SuperScript II RT (Life Technologies) was added, and the solution was incubated at $37^{\circ} \mathrm{C}$ for $60 \mathrm{~min}$. Following reverse transcription, $1 \mu 1$ of $2 \mathrm{U} / \mu \mathrm{l}$ E. coli RNase H (Life Technologies) was added to the first-strand cDNA solution. The solution was incubated at $37^{\circ} \mathrm{C}$ for $20 \mathrm{~min}$.

To anneal the primers in the synthesis of second-strand cDNA, $1 \mu \mathrm{l}$ of $100 \mu \mathrm{M}$ T7-oligo $\mathrm{dT}_{24}$ primer was added and incubated at $65^{\circ} \mathrm{C}$ for $5 \mathrm{~min}$, and at $42^{\circ} \mathrm{C}$ for $10 \mathrm{~min}$. To synthesize second-strand cDNA, $90 \mu \mathrm{l}$ of RNase-free water, $30 \mu \mathrm{l}$ of $5 \mathrm{X}$ second-strand buffer (Life Technologies), $3 \mu \mathrm{l}$ of $10 \mathrm{mM}$ dNTPs, $4 \mu \mathrm{l}$ of $10 \mathrm{U} / \mu \mathrm{l} E$. coli DNA polymerase I (Life Technologies) and $1 \mu \mathrm{l}$ of $2 \mathrm{U} / \mu \mathrm{l} E$. coli RNase $\mathrm{H}$ (Life Technologies) were added to the first-strand cDNA solution. The solution was incubated at $16^{\circ} \mathrm{C}$ for $2 \mathrm{~h}$. For the end smoothing of double-strand cDNA, $2 \mu \mathrm{l}$ of $5 \mathrm{U} / \mu \mathrm{l}$ T4 DNA polymerase (Life Technologies) was added, and the solution was incubated at $37^{\circ} \mathrm{C}$ for $5 \mathrm{~min}$. The synthesized double-strand cDNA was purified using phenol/chloroform, isopropanol and ethachinmate (Nippon Gene). The obtained pellets were washed twice with $70 \%$ ethanol and resolved in $14 \mu 1$ of RNase-free water.

TALPAT-step 4. To combine adaptor sequences of doublestranded cDNA, $2 \mu \mathrm{l}$ of $50 \mu \mathrm{M}$ EcoRI-NotI-BamHI adaptor (Takara Bio, Shiga, Japan), $2 \mu$ of 10X T4 DNA ligase reaction buffer, $1 \mu \mathrm{l}$ of $10 \mathrm{mM}$ ATP and $1 \mu \mathrm{l}$ of $350 \mathrm{U} / \mu \mathrm{l}$ T4 DNA ligase (Takara Bio) were added to the double-strand solution. The solution was incubated at $16^{\circ} \mathrm{C}$ for $16 \mathrm{~h}$.

To amplify adaptor-ligated double-strand cDNA by PCR, $63 \mu \mathrm{l}$ of DNase-free water, $10 \mu \mathrm{l}$ of 10X Ex Taq buffer, 12 $\mu \mathrm{l}$ of $25 \mathrm{mM} \mathrm{MgCl}_{2}, 10 \mu \mathrm{l}$ of $2.5 \mathrm{mM}$ dNTP, $3 \mu \mathrm{l}$ of $100 \mu \mathrm{M}$ adaptor primer (5'-GGAATTCGGCGGCCGCGGATCC-3'), $1 \mu 1$ of adaptor-ligated double-strand cDNA, and $1 \mu 1$ of $5 \mathrm{U} / \mu 1 \mathrm{Ex}$ Taq polymerase (Takara Bio) were mixed. PCR was performed using the Veriti 96 Well Thermal Cycler (Life Technologies) under the following conditions: denaturation at $95^{\circ} \mathrm{C}$ for $5 \mathrm{~min}, 30$ cycles each of denaturation at $95^{\circ} \mathrm{C}$ for $1 \mathrm{~min}$ and annealing and extension at $72^{\circ} \mathrm{C}$ for $3 \mathrm{~min}$, with a final extension step at $72^{\circ} \mathrm{C}$ for $10 \mathrm{~min}$. PCR products were purified using phenol/chloroform, isopropanol and ethachinmate (Nippon Gene). The obtained pellets were washed twice with $70 \%$ ethanol, resolved in Tris- $\mathrm{HCl}$ (TE) buffer $(10 \mathrm{mM}$ Tris- $\mathrm{HCl}$ and $1 \mathrm{mM}$ EDTA, $\mathrm{pH} 8.0$ ), and produced at a concentration of $0.5 \mu \mathrm{g} / \mu \mathrm{l}$.

TALPAT-step 5. To synthesize cRNA by $\mathrm{T} 7$ in vitro transcription, the AmpliScribe T7-Flash Transcription kit (Epicentre Biotechnologies) was used. Two microliters of $10 \mathrm{X}$ reaction buffer; $2.0 \mu \mathrm{l}$ of $100 \mathrm{mM}$ DTT; $1.8 \mu \mathrm{l}$ of each of $100 \mathrm{mM}$ dATP, dCTP, dGTP and dUTP; $0.5 \mu 1$ of RiboGuard RNase Inhibitor; $2 \mu \mathrm{l}$ of AmpliScribe T7-Flash Enzyme Solution and $1.0 \mu \mathrm{l}$ of $0.5 \mu \mathrm{g} / \mu \mathrm{l}$ PCR product solution from step 4 were added to $5.3 \mu \mathrm{l}$ of RNase-free water. The solution was then incubated at $37^{\circ} \mathrm{C}$ for $16 \mathrm{~h}$. To degrade double-strand cDNA, $1 \mu \mathrm{l}$ of RNase-free DNase I solution was added to this solution. The solution was 
Table I. Primer sequences for real-time PCR.

\begin{tabular}{llcc}
\hline Primer & \multicolumn{1}{c}{ Sequence $\left(5^{\prime} \rightarrow 3^{\prime}\right)$} & Size (mer) & PCR products (bp) \\
\hline hsGAPDH F & CCATGTAGACCCCTTGAAG & 19 & 83 \\
hsGAPDH R & GGTTGAGCACAGGGTACTTT & 20 & 61 \\
hsHMBS F & GAGAAGTCCAAGCAACAGC & 19 & 73 \\
hsHMBS R & CCTTCAGAACTGGTTTATTAGTAGG & 25 & 24 \\
hsHPRT1 F & GTAGTGTTTCAGTAATGTTGACTG & 22 & 90 \\
hsHPRT1 R & AACTGCTGACAAAGATTCACTG & 22 & 94 \\
hsRPL13A F & GCATGAGCTTGCTGTTGTACAC & 19 & 83 \\
hsRPL13A R & CATGGGCGATGCCTGTAAC & 19 & 24 \\
hsSDHA F & GAGATTGGCACCTAGTGGC & 24 & 101 \\
hsSDHA R & CATCTCACAAGAATGAAGCAAGGG & 24 & \\
hsTBP F & CAGTATTGCAGGACAGAATATATG & 18 & \\
hsTBP R & TTGTACAGAGTACTCTGAAGAAAG & 24 & \\
hsUBC F & AAAGAGTCCACTCTGCAC & & \\
hsUBC R & CTTTATTGAAAGGAAAGTGCAATG & & \\
\end{tabular}

Table II. Quantity of cRNA synthesized in TALPAT-step 2.

\begin{tabular}{lcrrrrr}
\hline & \multicolumn{5}{c}{ Reaction time of T7 in vitro transcription in TALPAT-step 2 } \\
\cline { 2 - 7 } Quantity of cRNA synthesized (ng) & $30 \mathrm{~min}$ & $1 \mathrm{~h}$ & $2 \mathrm{~h}$ & $4 \mathrm{~h}$ & $8 \mathrm{~h}$ & $16 \mathrm{~h}$ \\
\hline Quantity of starting samples & & & & & & \\
in TALPAT-step 1 (ng) & 694 & 1,382 & 2,034 & 2,399 & 4,208 & 5,748 \\
100 & 133 & 185 & 248 & 446 & 757 & 1,720 \\
10 & 105 & 144 & 203 & 314 & 587 & 1,161 \\
1 & & & & & &
\end{tabular}

incubated at $37^{\circ} \mathrm{C}$ for $15 \mathrm{~min}$, and $400 \mu \mathrm{l}$ of ISOGEN reagent was then added to it. The synthesized cRNA was extracted using the ISOGEN reagent, according to the manufacturer's instructions, and cRNA pellets were resuspended in $10 \mu \mathrm{l}$ of RNase-free water.

Electrophoresis of cRNA synthesized by the TALPAT method. To confirm the size of synthesized cRNA, electrophoresis on $1 \%$ denaturing agarose gel containing formaldehyde was performed using MOPS buffer (20 mM MOPS, $2 \mathrm{mM}$ sodium acetate and $1 \mathrm{mM}$ EDTA, pH 7.0) at $100 \mathrm{~V}$ for $20 \mathrm{~min}$. Subsequent to electrophoresis, the gel was stained with ethidium bromide and washed twice with RNase-free water. Bands were then detected by UV irradiation.

Real-time PCR. To confirm reproducibility and relative expression ratios of cRNA synthesized in TALPAT-step 2 and step 5, gene expression of the seven housekeeping genes, glyceraldehyde-3-phosphate dehydrogenase $(G A P D H)$, hydroxymethylbilane synthase $(H M B S)$, hypoxanthine phosphoribosyltransferase (Lesch-Nyhan syndrome) (HPRT1), ribosomal protein L13a (RPL13A), succinate dehydrogenase complex subunit A flavoprotein (Fp) (SDHA), TATA box binding protein $(T B P)$ and ubiquitin $\mathrm{C}(U B C)$ were examined by real-time PCR using the primer pairs shown in Table I.

To obtain cDNA derived from cRNA, $500 \mathrm{ng}$ of cRNA was used for the reverse transcription reaction. These reactions were performed using the High Capacity cDNA Reverse Transcriptase kit (Life Technologies), according to the manufacturer's instructions. Real-time PCR was performed using cDNA derived from cRNA, Power SYBR-Green Master mix (Life Technologies), primer pairs shown in Table I and the StepOne Plus Real-Time PCR system (Life Technologies), under the following conditions: $10 \mathrm{~min}$ at $95^{\circ} \mathrm{C}$, followed by 40 cycles each of $95^{\circ} \mathrm{C}$ for $15 \mathrm{sec}$ and $60^{\circ} \mathrm{C}$ for $60 \mathrm{sec}$. Relative expression ratios were compared using the comparative $\mathrm{Ct}$ $(\Delta \Delta \mathrm{Ct})$ method.

\section{Results and Discussion}

Correlation between the quantity of starting samples and reaction time of $T 7$ in vitro transcription. Total RNA from the A549 cells was extracted using the ISOGEN reagent, according to the manufacturer's instructions. To estimate the quality of total RNA, the measurement of absorbance and electrophoresis of total RNA obtained were carried out. 


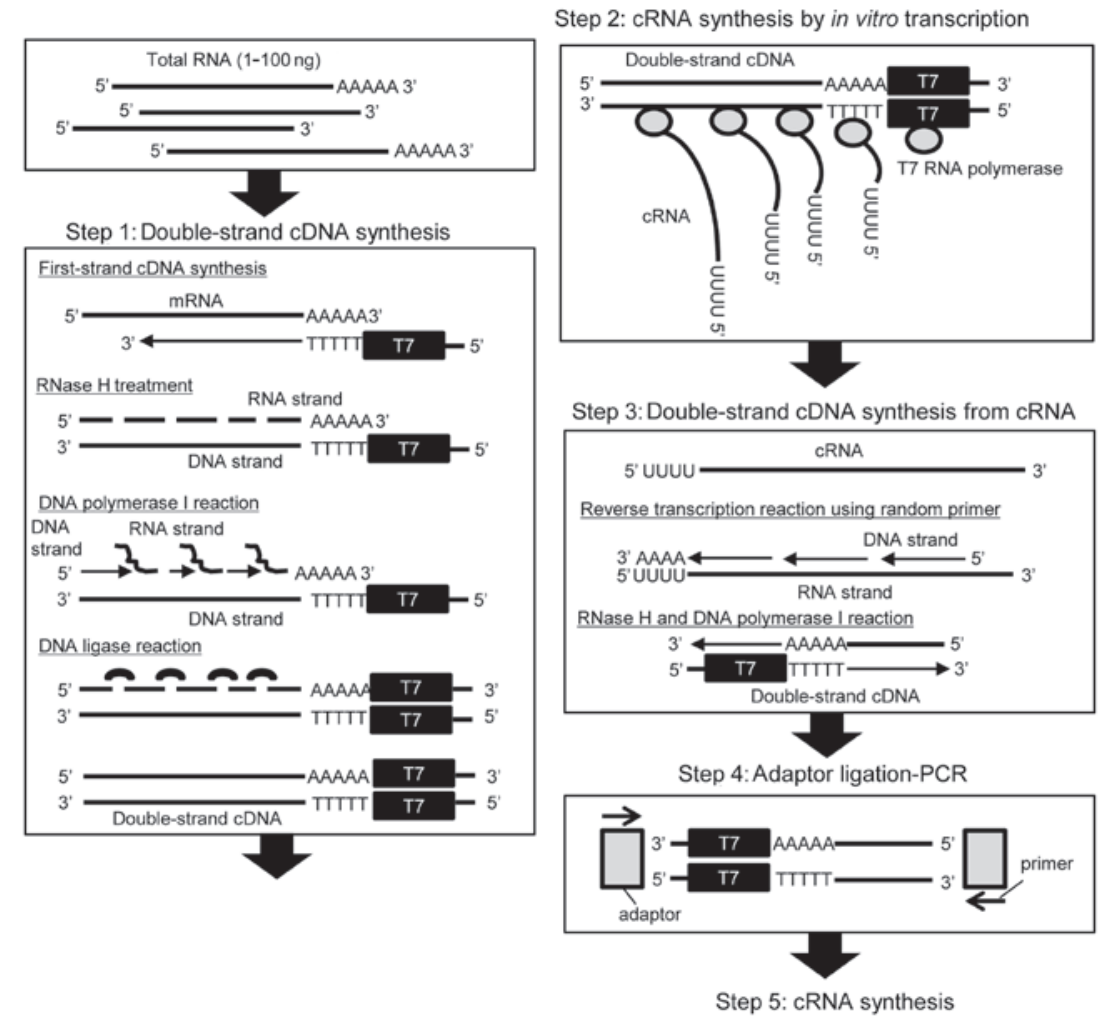

Figure 1. Schematic presentation of the TALPAT method is shown. The TALPAT method is performed in a 5-step enzymatic reaction, as described in Materials and methods: step 1, synthesis of double-strand cDNA with T7 promoter using a small amount of total RNA and T7-oligo $\mathrm{dT}_{24}$ primer; step 2, synthesis of cRNA using T7 RNA polymerase and synthesis of double-strand cDNA with T7 promoter; step 3, synthesis of double-strand cDNA with T7 promoter using random primer and $\mathrm{T} 7$-oligo $\mathrm{dT}_{24}$ primer; step 4, adaptor-ligation and PCR using adaptor primer; step 5, synthesis of cRNA using T7 RNA polymerase and synthesis of double-strand cDNA with T7 promoter.

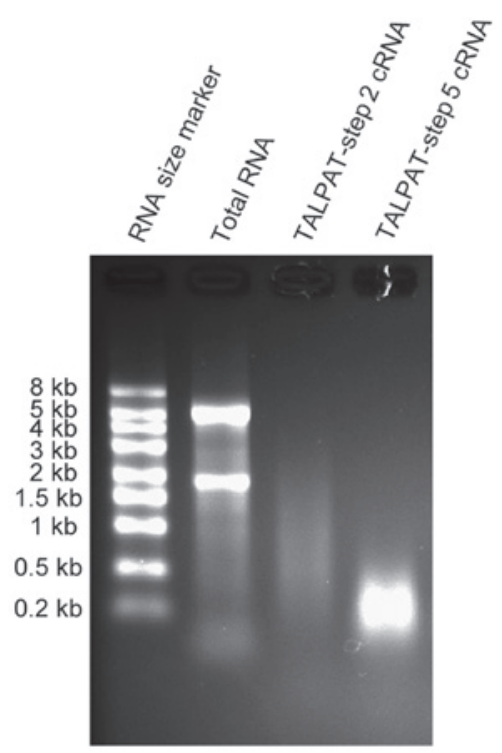

Figure 2. Electrophoresis of cRNA synthesized in TALPAT-step 2 and -step 5 is shown. The size of cRNA synthesized by the TALPAT method was examined by electrophoresis on $1 \%$ denaturing agarose gel. cRNA synthesized in TALPATstep 2 was detected to be ranging from 0.2 to $2.0 \mathrm{~kb}$. In addition, cRNA obtained from TALPAT-step 5 was primarily detected ranging from 0.2 to $0.5 \mathrm{~kb}$.

The 260/280 nm absorbance ratio of total RNA was 2.0 (data not shown). In addition, the bands of $18 \mathrm{~S}$ and $28 \mathrm{~S}$ ribosomal RNA were detected at a ratio of $\sim 1: 2$, after electrophoresis of total RNA on $1 \%$ denaturing agarose gel (data not shown), indicating that total RNA obtained was suitable for mRNA amplification.

To examine the correlation between the quantity of the starting sample and the reaction time of $\mathrm{T} 7$ in vitro transcription, TALPAT-step 1 was performed using 1, 10 and $100 \mathrm{ng}$ of diluted total RNA as the starting sample. In addition, the T7 in vitro transcription reaction in TALPAT-step 2 was performed for $30 \mathrm{~min}, 1,2,4,8$ and $16 \mathrm{~h}$. As shown in Table II, cRNA was amplified $>100$-fold, when the $\mathrm{T} 7$ in vitro transcription reaction was performed for $30 \mathrm{~min}$ in TALPAT-step 2, using double-strand cDNA derived from $1 \mathrm{ng}$ of total RNA. In addition, the quantity of synthesized cRNA in TALPAT step 2 increased depending on the quantity of the starting sample and reaction time. This finding indicates that the most efficient cRNA amplification is obtained when the T7 in vitro transcription reaction in TALPAT-step 2 is performed for $30 \mathrm{~min}$ and, that the quantity of synthesized cRNA is dependent on the quantity of the starting sample and reaction time.

Detection of cRNA fragments synthesized in TALPAT-step 2 and -step 5. To amplify the additional quantity of cRNA, TALPAT step 3-step 5 were performed using cRNA fragments synthesized in step 2. It is assumed that the mean length of the first-strand cDNA is reduced in step 3 , since random hexamer primers are used for the synthesis of first-strand cDNA from cRNA obtained from step 2 (Fig. 1). Therefore, we examined the length of cRNA synthesized in step 2 and step 5 by electrophoresis on $1 \%$ denaturing agarose gel and detected the 
A

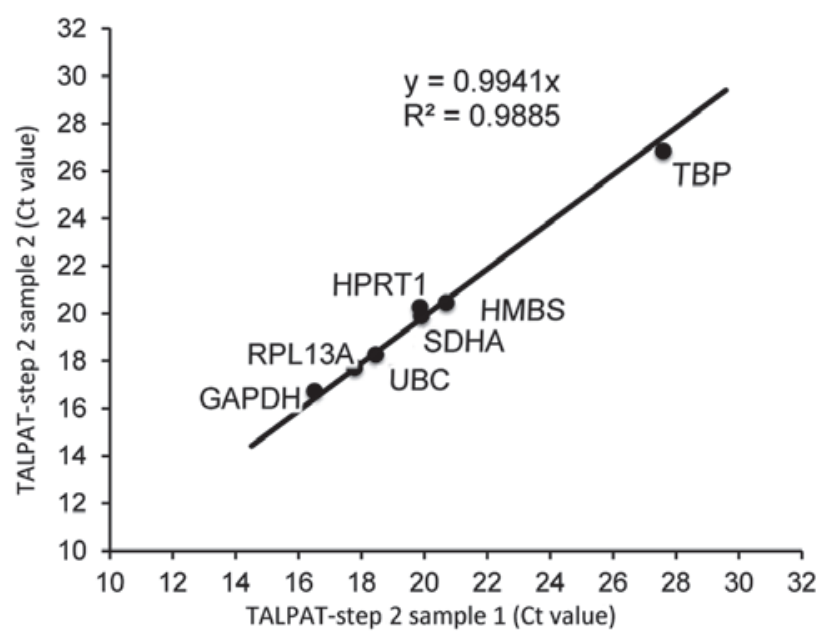

B

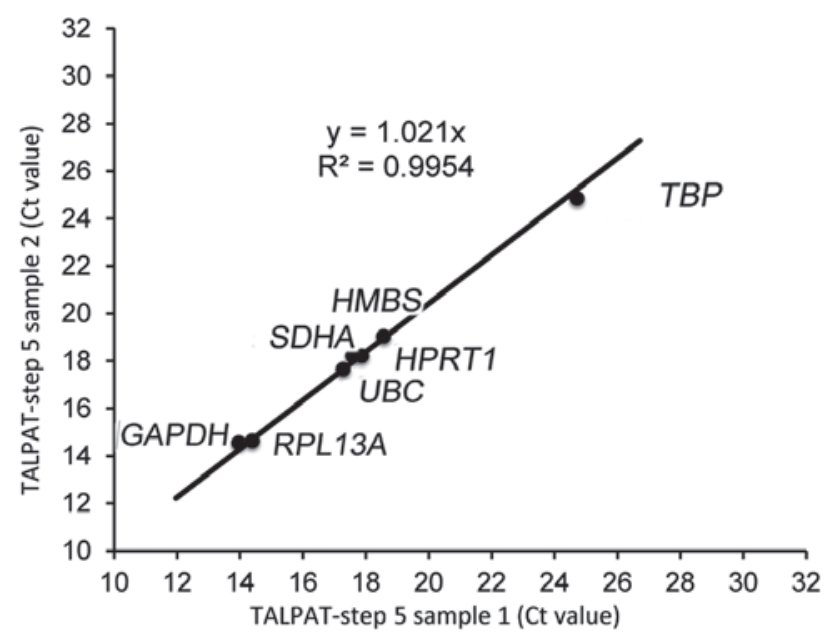

Figure 3. Evaluation of reproducibility of TALPAT-step 2 and step 5 is shown.Reproducibility of the TALPAT method was examined by real-time PCR using cRNA obtained by the same procedure from two samples. Ct values of seven housekeeping genes, GAPDH, HMBS, HPRT1, RPL13A, SDHA, TBP and UBC, were examined by real-time PCR using cRNA obtained from TALPAT-step 2 and -step 5. Scatter plot analysis was performed using Ct values obtained by real-time PCR. The square of the correlation coefficient $\left(\mathrm{R}^{2}\right)$ was calculated to estimate reproducibility of the TALPAT method. cRNA amplification by the TALPAT method indicated high reproducibility. Scatter plot of Ct values from (A) TALPAT-step 2 and (B) TALPAT-step 5.

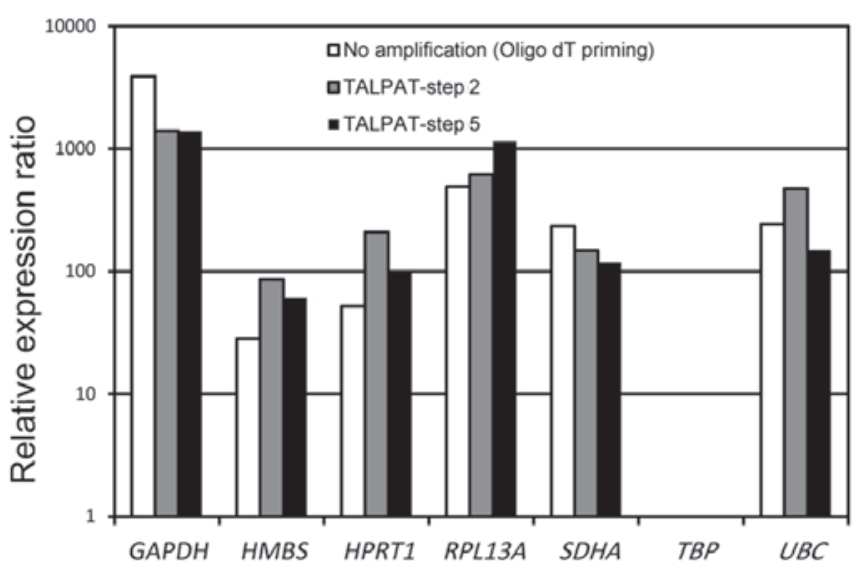

Figure 4. Examination of changes in the relative expression by the TALPAT method is shown. Changes in the relative expression by the TALPAT method were examined by real-time PCR using cRNA obtained from TALPAT-step 2 and -step 5. Reverse transcription was performed using $500 \mathrm{ng}$ cRNA or total RNA, as described in Materials and methods. Expression values of housekeeping genes were normalized based on expression values of TBP. Gene expression levels were almost the same among cRNA obtained by oligo dT priming (white column), TALPAT-step 2 (gray column) and TALPAT-step 5 (black column).

fragments of cRNA using ethidium bromide staining. In this experiment, $10 \mathrm{ng}$ of total RNA obtained from TALPAT-step 1 was used. T7 in vitro transcription in TALPAT-step 2 was performed for $16 \mathrm{~h}$. As shown in Fig. 2, the size of cRNA amplified in TALPAT-step 2 was $\sim 0.2-3.0 \mathrm{~kb}$ and the size of cRNA amplified in TALPAT-step 5 was $\sim 0.2-0.5 \mathrm{~kb}$. This observation shows that the region up to $0.2-0.5 \mathrm{~kb}$ from the $3^{\prime}$ end of mRNA is primarily amplified in TALPAT-step 5 and, that the size of amplified cRNA decreases depending on the processing step of the TALPAT method. cRNA amplified by the TALPAT method may be able to be used in microarray systems, such as Whole Human Genome DNA microarray provided by Agilent

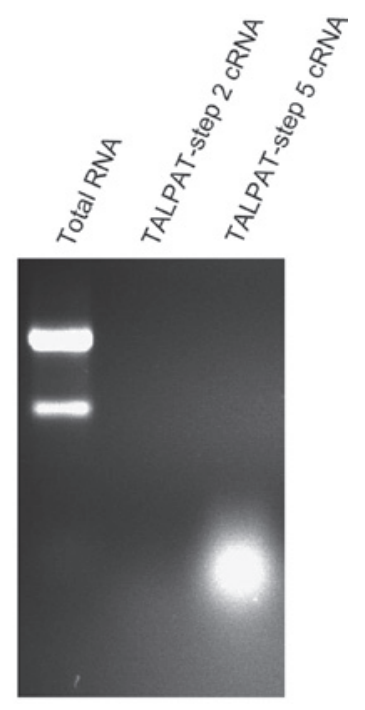

Figure 5. Electrophoresis of cRNA synthesized by the TALPAT method from total RNA of a single cell equivalent amount is shown. To examine whether or not the amplification from total RNA of a single cell amount is possible, the TALPAT method was applied, using 20 pg total RNA from A549 cells. cRNA synthesized by the TALPAT method was examined by electrophoresis on $1 \%$ denaturing agarose gel. cRNA synthesized in TALPAT-step 2 was barely detectable. However, cRNA synthesized in TALPAT-step 5 was clearly detected to be ranging from 0.2 to $0.5 \mathrm{~kb}$.

Technologies, since the sequence regions for mRNA detection are generically designed in the region at the $3^{\prime}$ end of mRNA.

As shown in Fig. 1, the TALPAT method is suitable for amplification of poly (A)-positive RNA, such as mRNA, since T7-oligo $\mathrm{dT}_{24}$ primer is used for the synthesis of the first-strand cDNA. Previously, natural antisense transcripts (NATs), which are transcribed from the DNA strand as opposed to the sense strand, have been identified by full-length cDNA analyses in humans and mice $(12,13)$. Several NATs, such as HIF-1 $\alpha$ NATs have poly(A)-tails at the 3 ' end (14). In addition, large intervening 
non-coding RNA (linc RNA), a long non-coding RNA with a poly(A)-tail at the 3 ' end, has been identified (15). The TALPAT method may be suitable for amplifying poly (A)-positive noncoding RNA, such as several NATs and linc RNA.

Reproducibility of the TALPAT method. To confirm the reproducibility of the TALPAT method, real-time PCR analysis was performed using cRNA obtained from two samples by the procedures described in Materials and methods. Ct values of seven housekeeping genes, GAPDH, HMBS, HPRT1, RPL13A, $S D H A, T B P$ and $U B C$, were determined by real-time PCR using cRNA obtained from TALPAT-step 2 and -step 5. Scatter plot analysis was performed using $\mathrm{Ct}$ values obtained by real-time PCR. The square of the correlation coefficient $\left(\mathrm{R}^{2}\right)$ of the seven housekeeping genes was calculated to estimate reproducibility of the TALPAT method. The linearity of the scatter plots was highly correlated between the two samples in step $2\left(\mathrm{R}^{2}=0.9885\right)$ as well as step $5\left(\mathrm{R}^{2}=0.9954\right)$ (Fig. 3$)$, indicating the high reproducibility of this method.

Relative changes in gene expression by the TALPAT method. To confirm relative changes in gene expression by the TALPAT method, real-time PCR of the above-mentioned seven housekeeping genes was performed using cRNA synthesized in TALPAT-step 2 and -step 5. Analysis of gene expression from total RNA without amplification by the TALPAT method was performed using the oligo-dT priming method. To compare real-time PCR results, expression values of the housekeeping genes were normalized based on expression values of TBP in the amplified samples. As shown in Fig. 4, few changes were observed among the relative expression ratios of the examined housekeeping genes. This indicates that the TALPAT method can synthesize cRNA with a constant ratio among the seven housekeeping genes.

Amplification from total RNA of a single cell equivalent amount. To determine applications of the TALPAT method, we examined whether or not amplification from total RNA of a single cell equivalent amount is possible. Twenty picograms of total RNA from the A549 cells were used in this experiment. Amplified cRNA from TALPAT-step 2 and -step 5 was electrophoresed on $1 \%$ denaturing agarose gel and detected by ethidium bromide staining. As shown in Fig. 5, cRNA amplified in TALPAT-step 2 is difficult to detect, due to the extremely low quantities of the starting sample. However, cRNA of $0.2-0.5 \mathrm{~kb}$ was detected in TALPAT-step 5, indicating that mRNA amplification from a single cell may be possible using this method.

Aoyagi et al demonstrated that high-fidelity mRNA amplification from a small amount of total RNA obtained by laser-captured microdissection was possible using the TALPAT method (7). Recently, a small amount of RNA has been detected from exosomes of various body fluids, such as serum/plasma, urine, as well as amniotic and ascites fluid (16-20). The TALPAT method may be suitable for mRNA and poly(A)-positive non-coding RNA amplification using a small amount of total RNA from body fluids, and thus be useful in the identification of biomarkers.

In conclusion, cRNA amplification by the TALPAT method was confirmed to be highly reproducible. Relative expression ratios among the housekeeping genes examined were constant.
In addition, cRNA amplification from 20 pg of total RNA was possible. This method may be suitable for mRNA and poly (A)-positive non-coding RNA amplification using a small amount of RNA from single, laser-captured or sorted cells, as well as exosomes from serum, urine or other body fluids.

\section{Acknowledgements}

This study was supported in part by a grant from KAKENHI (no. 23790613), Grant-in-Aid for Young Scientists (B). This study was also supported by the Takeda Science Foundation and the Hirosaki University Grant for Exploratory Research by Young Scientists.

\section{References}

1. Schena M, Shalon D, Davis RW and Brown PO: Quantitative monitoring of gene expression patterns with a complementary DNA microarray. Science 270: 467-470, 1995.

2. Lander ES, Linton LM, Birren B, et al: Initial sequencing and analysis of the human genome. Nature 409: 860-921, 2001.

3. Venter JC, Adams MD, Myers EW, et al: The sequence of the human genome. Science 291: 1304-1351, 2001.

4. International Human Genome Sequencing Consortium: Finishing the euchromatic sequence of the human genome. Nature 431: 931-945, 2004.

5. Okazaki Y, Furuno M, Kasukawa T, et al: Analysis of the mouse transcriptome based on functional annotation of 60,770 full-length cDNAs. Nature 420: 563-573, 2002.

6. Carninci P, Kasukawa T, Katayama S, et al: The transcriptional landscape of the mammalian genome. Science 309: 1559-1563, 2005.

7. Aoyagi K, Tatsuta T, Nishigaki M, et al: A faithful method for PCR-mediated global mRNA amplification and its integration into microarray analysis on laser-captured cells. Biochem Biophys Res Commun 300: 915-920, 2003.

8. Isohata N, Aoyagi K, Mabuchi T, et al: Hedgehog and epithelial-mesenchymal transition signaling in normal and malignant epithelial cells of the esophagus. Int J Cancer 125: 1212-1221, 2009.

9. Wang E, Miller LD, Ohnmacht GA, Liu ET and Marincola FM: High-fidelity mRNA amplification for gene profiling. Nat Biotechnol 18: 457-459, 2000.

10. Ko MS, Ko SB, Takahashi N, Nishiguchi K and Abe K: Unbiased amplification of a highly complex mixture of DNA fragments by 'lone linker'-tagged PCR. Nucleic Acids Res 18: 4293-4294, 1990.

11. Lucito R, Nakimura M, West JA, et al: Genetic analysis using genomic representations. Proc Natl Acad Sci USA 95: 4487-4492, 1998.

12. Rosok O and Sioud M: Systematic identification of sense-antisense transcripts in mammalian cells. Nat Biotechnol 22: 104-108, 2004.

13. Katayama S, Tomaru Y,Kasukawa T, et al: Antisense transcription in the mammalian transcriptome. Science 309: 1564-1566, 2005.

14. Bertozzi D, Iurlaro R, Sordet O, et al: Characterization of novel antisense HIF-1 $\alpha$ transcripts in human cancers. Cell Cycle 10: 3189-3197, 2011.

15. Guttman M, Amit I, Garber M, et al: Chromatin signature reveals over a thousand highly conserved large non-coding RNAs in mammals. Nature 458: 223-227, 2009.

16. Mathivanan S, Ji H and Simpson RJ: Exosomes: extracellular organelles important in intercellular communication. J Proteomics 73: 1907-1920, 2010.

17. Michael A, Bajracharya SD, Yuen PS, et al: Exosomes from human saliva as a source of microRNA biomarkers. Oral Dis 16: 34-38, 2010.

18. Moon PG, You S, Lee JE, Hwang D and Baek MC: Urinary exosomes and proteomics. Mass Spectrom Rev 30: 1185-1202, 2011.

19. Brase JC, Wuttig D, Kuner R and Sultmann H: Serum microRNAs as non-invasive biomarkers for cancer. Mol Cancer 9: 306, 2010.

20. Lasser C, Alikhani VS, Ekstrom K, et al: Human saliva, plasma and breast milk exosomes contain RNA: uptake by macrophages. J Transl Med 9: 9, 2011. 